\title{
The catastrophic landfill flowslide at Hongao dumpsite on 20 December 2015 in Shenzhen, China
}

\author{
Qiang Xu${ }^{1}$, Dalei Peng ${ }^{1}$, Weile $\mathrm{Li}^{1}$, Xiujun Dong ${ }^{1}$, Wei Hu${ }^{1}$, Minggao Tang ${ }^{1}$, and Fangzhou Liu ${ }^{2}$ \\ ${ }^{1}$ State Key Laboratory of Geohazard Prevention and Geoenvironment Protection, Chengdu University of Technology, \\ Chengdu 610059, China \\ ${ }^{2}$ School of Civil and Environmental Engineering, Georgia Institute of Technology, Atlanta, GA, USA \\ Correspondence to: Fangzhou Liu (fangzhou.liu@gatech.edu)
}

Received: 31 May 2016 - Discussion started: 20 June 2016

Revised: 18 January 2017 - Accepted: 24 January 2017 - Published: 24 February 2017

\begin{abstract}
A catastrophic flowslide occurred at the Hongao dumpsite on 20 December 2015 in the Guangming New District of Shenzhen, China. The flowslide caused 77 causalities and damaged 33 buildings. In the absence of extreme weather conditions and seismic activity, the causes of the failure were analyzed on the basis of multi-temporal remote-sensing images, site investigation, in situ tests, laboratory tests, and numerical analyses. Site investigations showed that the volume of the displaced material was $2.32 \times 10^{6} \mathrm{~m}^{3}$ and the volume of the pre-failure waste filling was $6.27 \times 10^{6} \mathrm{~m}^{3}$. The flowslide was characterized by high travel velocity and long runout distance. The displaced material was primarily a mixture of silty soil and construction and demolition waste with water content of 17.3-42.4\%. The primary causes of the failure were concluded to be the following: (1) groundwater flow had stagnated in the dumpsite due to drainage system failure and the underlying impermeable granite stratum; (2) the accumulation rate and total volume of the waste filling was in exceedance of the design capacity. The flowslide may be ascribed to the development of excess pore-water pressure as evidence of liquefaction was observed at several locations, and it is postulated that such phenomena were related to the surcharge loads imposed by the unregulated disposal activities.
\end{abstract}

\section{Introduction}

Owing to population growth and industrialization, rapid increase in the accumulation rate of municipal solid waste (MSW) poses challenges in MSW management and urban planning (Huang and Cheng, 2017). As landfilling is the most common method of MSW disposal (Brunner and Fellner, 2007), transforming an abandoned quarry to a dumpsite conserves resources by reclaiming the quarry space and provides MSW storage solution (Zou, 2016). The landfill slope stability is critical to the MSW management, and thus the selection and design of landfills require engineering assessment on both slope stability and environment impact.

The porosity and water content of MSW is typically high in an unregulated landfill because of inadequate drainage system, and therefore failures of MSWs commonly exhibit flowlike behaviors, i.e., flowslide, with extremely high mobility (e.g., Dai et al., 2016; Huang and Cheng, 2017). Landfill slope failure at MSW dumpsites can be found in previous studies, wherein six reported cases between 1993 and 2005 resulted in approximately 500 deaths and significant economic loss (Blight, 2008; Blight and Fourie, 2005; Eid et al., 2000; Kjeldsen and Fischer, 1995; Kocasoy and Curi, 1995; Merry et al., 2005; Mitchell et al., 1990). The deadliest event in history killed 278 people in Manila, Philippines, in 2000, and the second deadliest event killed 143 people and buried 71 houses on 21 February 2005 at the Leuwigajah dumpsite near Bandung, Indonesia (Lavigne et al., 2014).

Shear strength of MSW is a function of various parameters, including the type and composition of the waste, disposal rate, water content, surcharge, and compaction (Eid et al., 2000; Huvaj-Sarihan and Stark, 2008). The movement of waste failure is complex and still poorly known due to the lack of field monitoring data. The previous literature has focused on empirical methods (e.g., Blight and Fourie, 2005; Srour, 2011), laboratory experiments, and numerical analy- 
ses. An energy balance approach was presented to estimate the maximum flow velocity of MSW slope failure (Blight and Fourie, 2005). The empirical-statistical method still has widespread use in practical applications, but the accuracy is model-dependent (Dai et al., 2016; Huang and Cheng, 2017). A mixture of peat, kaolinite, and quartz sand was used in laboratory tests to study the interplay between water content of filling and MSW failure, of which the results shown that, with increased water content of the MSW, the mobility increases while the maximum and final flow depth decrease (Dai et al., 2016). Numerical simulation has been widely used in landfill slope stability analysis (e.g., Chang, 2002, 2005; Chugh et al., 2007; Huang and Cheng, 2017); some of the more advanced methods include the application of the smoothed-particle hydrodynamics (SPH) method (e.g., Huang et al., 2013) and the moving-particle semi-implicit (MPS) method (e.g., Huang and Zhu, 2014) for runout distance analysis of landfill flowslide.

A MSW landfill consisting of mainly construction and demolition waste failed at the Hongao dumpsite in the Guangming New District of Shenzhen, China, at approximately 11:30 LT on 20 December 2015. The flowslide destroyed 33 buildings in the downstream industrial park and resulted in 77 causalities. No extreme weather or seismic activity was reported at the time of the event. This article investigates the characteristics and causes of failure. Field investigation, in situ tests, unmanned aerial vehicle (UAV) stereomeasurements, and remote-sensing images were used to analyze properties and characteristics of the failure. Laboratory tests and back calculations were performed to better understand the failure mechanism.

\section{Data and methodology}

A series of satellite images of the site was obtained from Google Earth between November 2002 and February 2016. Two high-resolution pre-/post-failure images were acquired by satellite imaging and aerial photography. Topography map of the pre-disposal site was provided by the local government. The dumpsite design was submitted by a third-party consulting firm in December 2013. Based on the official report on the incident, the design capacity was $4 \times 10^{6} \mathrm{~m}^{3}$ with nine slope benches at an average ratio of $1: 2.5$. For the volume of the pre-failure dumpsite filling, field and UAV measurements suggested an upper bound of $6.27 \times 10^{6} \mathrm{~m}^{3}$, with a lower bound of $5.83 \times 10^{6} \mathrm{~m}^{3}$ by Yin et al. (2016). The digital orthoimage map (DOM) and digital surface model (DSM) were reconstructed from aerial photos, and a topographic map of the post-sliding dumpsite was generated from the DSM at a scale of $1: 1000$. Three platforms were structured at the study site for vehicles. A topographic map of the pre-failure dumpsite was derived by combining the original, pre-failure, and post-failure slope images, which also provided an estimation on the volume and depth of the pre/post-failure landfill.

The preliminary field investigation was conducted on 22 December 2015, with a follow-up investigation on 21-25 January 2016. Field investigations evaluated the topographical, geological, and groundwater conditions. Density, water content, and permeability of the displaced material were measured in situ. Undisturbed and reconstituted soil samples were obtained and used for laboratory tests, including weathered silty soil and waste fillings. Grain size distribution was conducted using wet-sieve analysis. Dry density and the optimum water content of the displaced material were determined by a standard compaction test. The shear strength of the displaced material was obtained from a triaxial compression test. In order to back-analyze the failure of the dumpsite, input parameters for the material properties and model geometry were measured on site or in the laboratory. The mobilized shear strength was back-calculated using the conventional limit equilibrium method (LEM) to demonstrate the complexity of such progressive failure involving liquefaction and post-failure landslide propagation.

\section{Geological and climatic setting}

The location of the site is shown in Fig. 1a, of which the prefailure image was obtained by Pléiades image on 18 December 2015 ( 2 days before failure) and the post-failure aerial image was taken by UAV ( 3 days after failure) as shown in Fig. $1 \mathrm{~b}$ and c. The dumpsite was located $23 \mathrm{~km}$ north of Shenzhen and $5 \mathrm{~km}$ south of the Guangming New District $\left(113^{\circ} 56^{\prime} 5^{\prime \prime} \mathrm{E}, 22^{\circ} 42^{\prime} 44^{\prime \prime} \mathrm{N}\right)$. The dumpsite was surrounded by three ridges with a free face excavated in a mild slope gradient. The bedrock of the dumpsite is mainly Cretaceous granite rock (Fig. 2a and b). The landfill consisted of construction waste mixed with silty soil, clay, rock, and gravel (Figs. 2 and 3).

The study area belongs to the subtropical monsoon climate zone with an average temperature of $22^{\circ} \mathrm{C}$ and an average annual precipitation of $1500 \mathrm{~mm}$ concentrating between April and September (greater than $85 \%$ of the annual rainfall) (Zhang et al., 2006). Based on the rainfall data from the nearby Tangjia rainfall station (Fig. 4), a heavy rainfall occurred on 9 December 2015 with an accumulated precipitation of $67.8 \mathrm{~mm}$; however, no substantial evidence shows direct correlation between the flowslide and this particular rainfall event. The catchment area (Fig. 5a) was estimated as $4.7 \times 10^{5} \mathrm{~m}^{2}$, which was nearly 3 times greater than the area of the dumpsite $\left(1.6 \times 10^{5} \mathrm{~m}^{2}\right)$. A drainage system was implemented to collect surface runoff by the drainage pipes installed at a higher elevation above the dumpsite and divert it into the peripheral drainage channels. Field evidence suggested that the drainage system was abandoned, possibly due to the lack of maintenance (Fig. 5b and c). With the inadequate drainage, ingress of rainwater in the dumpsite was per- 

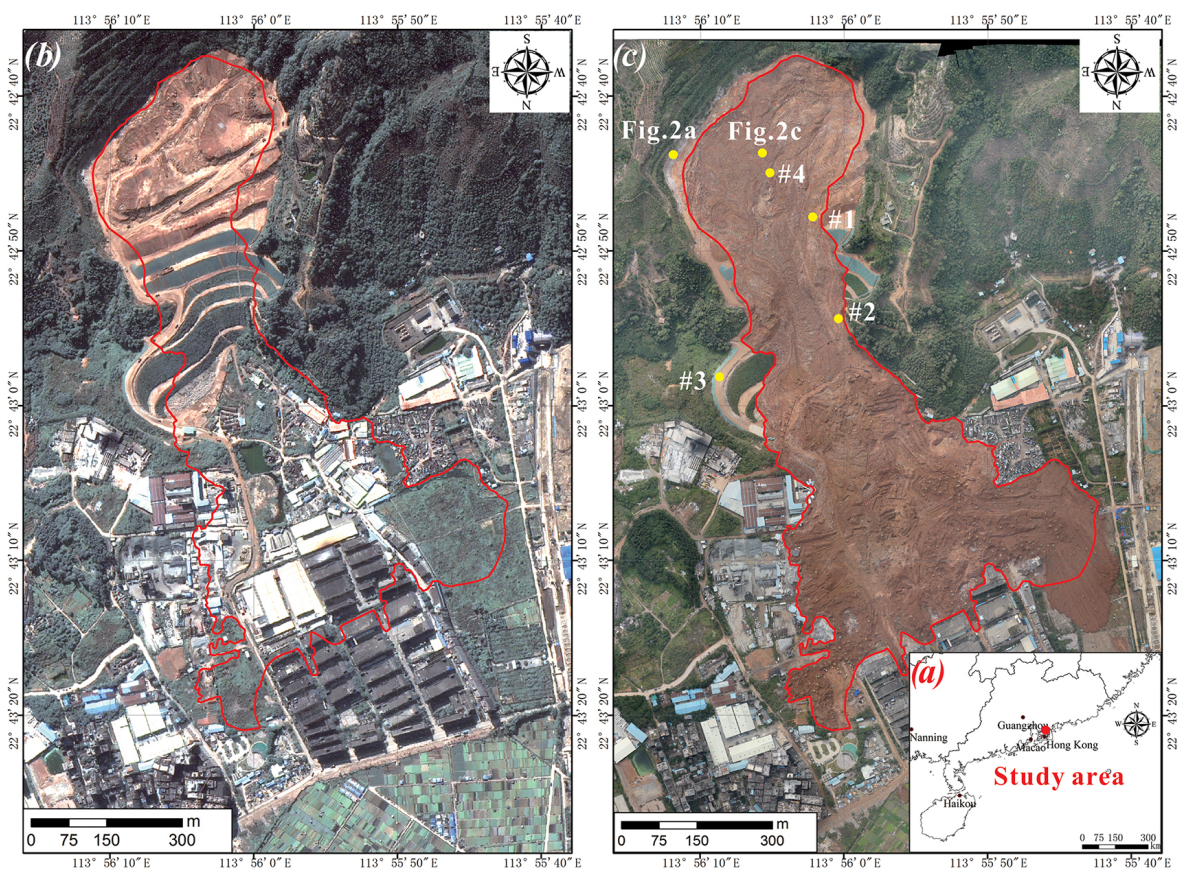

Figure 1. Location of the study site and images of the pre-/post-failure dumpsite. The boundary of the flowslide is indicated in red. (a) Location of the study area; (b) Pléiades satellite image (18 December 2015); (c) aerial photo with DEM of the flowslide with locations of samples for laboratory tests (23 December 2015).

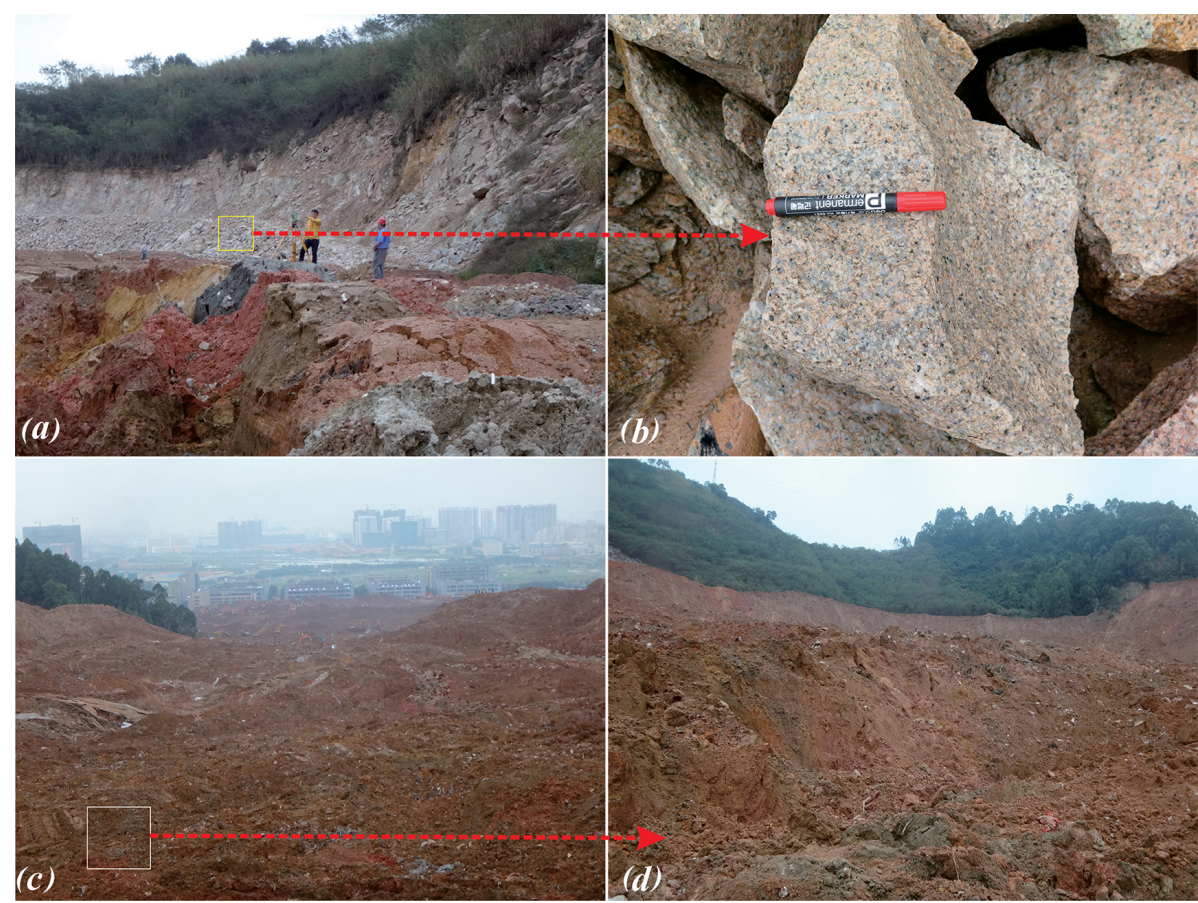

Figure 2. Photos of the rock and soil specimen collected from the displaced material. (a) Exposed granite rock near the flowslide scarp; (b) close view of the granite rocks; (c) displaced material in the zone of depletion; (d) materials in the flowslide source area. 


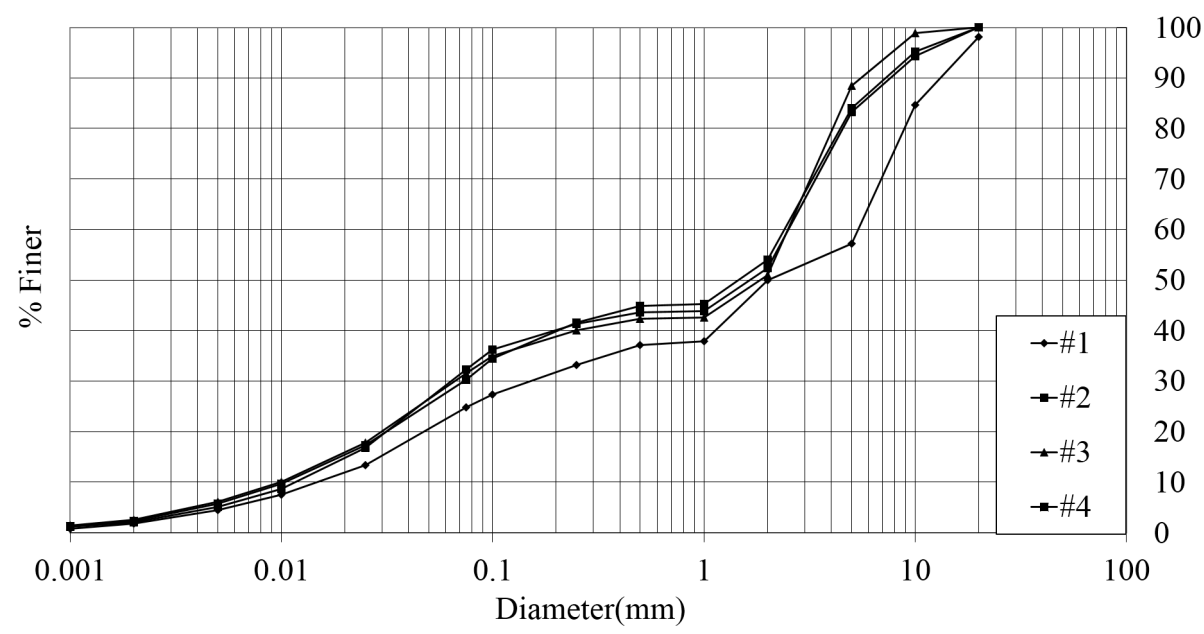

Figure 3. Particle size distribution of the waste filling (with sieve sizes of $20,10,5,2.0,1,0.5,0.25,0.10,0.075,0.025,0.01,0.005,0.002$, and $0.001 \mathrm{~mm}$ ).

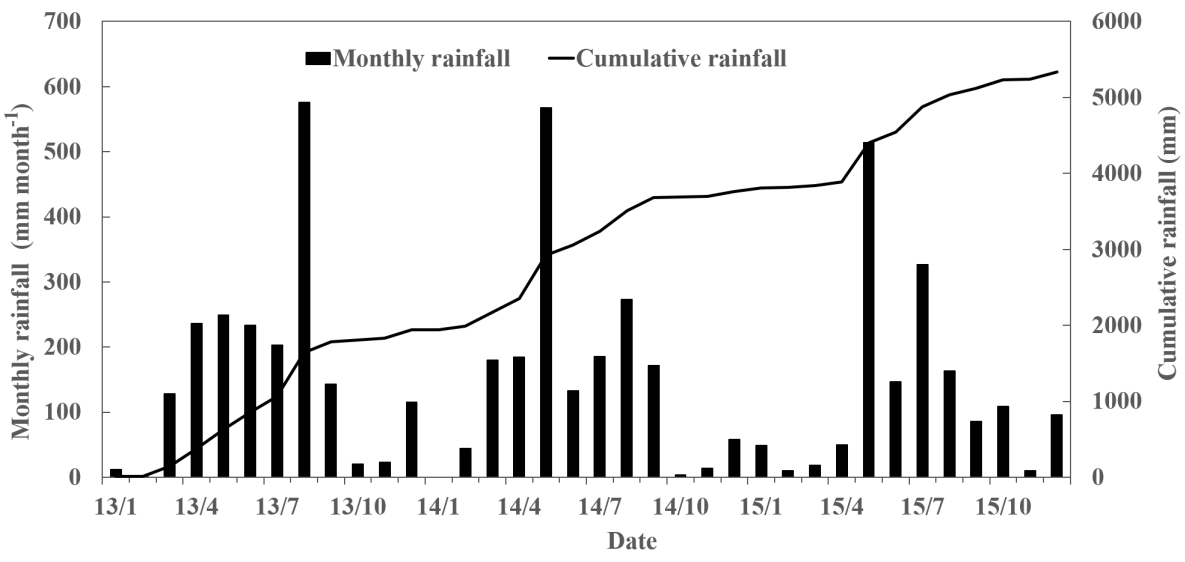

Figure 4. Monthly rainfall and cumulative precipitation between January 2013 and December 2015.

mitted (Fig. 6c), in addition to the concentration of surface runoff and groundwater into the dumpsite. The infiltration rate of the waste filling was estimated as $5.26 \times 10^{-6} \mathrm{~cm} \mathrm{~s}^{-1}$ by using a field double-ring infiltrometer. Low permeability and inadequate drainage resulted in high water content and high pore-water pressure in the dumpsite. The groundwater in the study area was mainly bedrock fissure water and Quaternary pore water (Fig. 6).

\section{Multi-temporal remote-sensing images}

The development of dumpsite and landform changes is presented by a series of remote-sensing images taken between 2002 and 2016 (Fig. 7). It is postulated that the quarry was active between 2002 and 2008, during which time formation of ponds of various sizes at different spatial and temporal locations in the quarry indicated low permeability and the lack of a drainage network (Fig. $7 \mathrm{~b}$, c, and d). The quarry was abandoned in or before 2008 as shown in Fig. 7c (20 February 2008) with a small amount of waste filling in the pit. A large-scale pond was subsequently formed by rainfall and groundwater (Fig. 7d). The depth of the pit was over $100 \mathrm{~m}$ before routine disposal activities. A service road was excavated between two rock hills exiting the quarry and formed a small-scale gully across the pit longitudinally (Fig. 7a, b, c, and d). Additionally, a small-scale platform (office area of the abandoned quarry) was excavated immediately downstream of the quarry exit. The gully was later covered by a multibenched retaining slope, with a gradient of $15-18^{\circ}$, between the rock hills, and waste disposal continued throughout the process (Fig. 7e). Disposal activity started possibly in 2014 (Fig. 7e and f), and the accumulation rate of the waste filling was considerably fast (Zou, 2016).

An unpaved road was excavated on the east side of the quarry, connecting the crest and the toe of the hillslope (Fig. 7e). A large number of trucks can be seen transporting construction waste to the dumpsite, and a large amount 

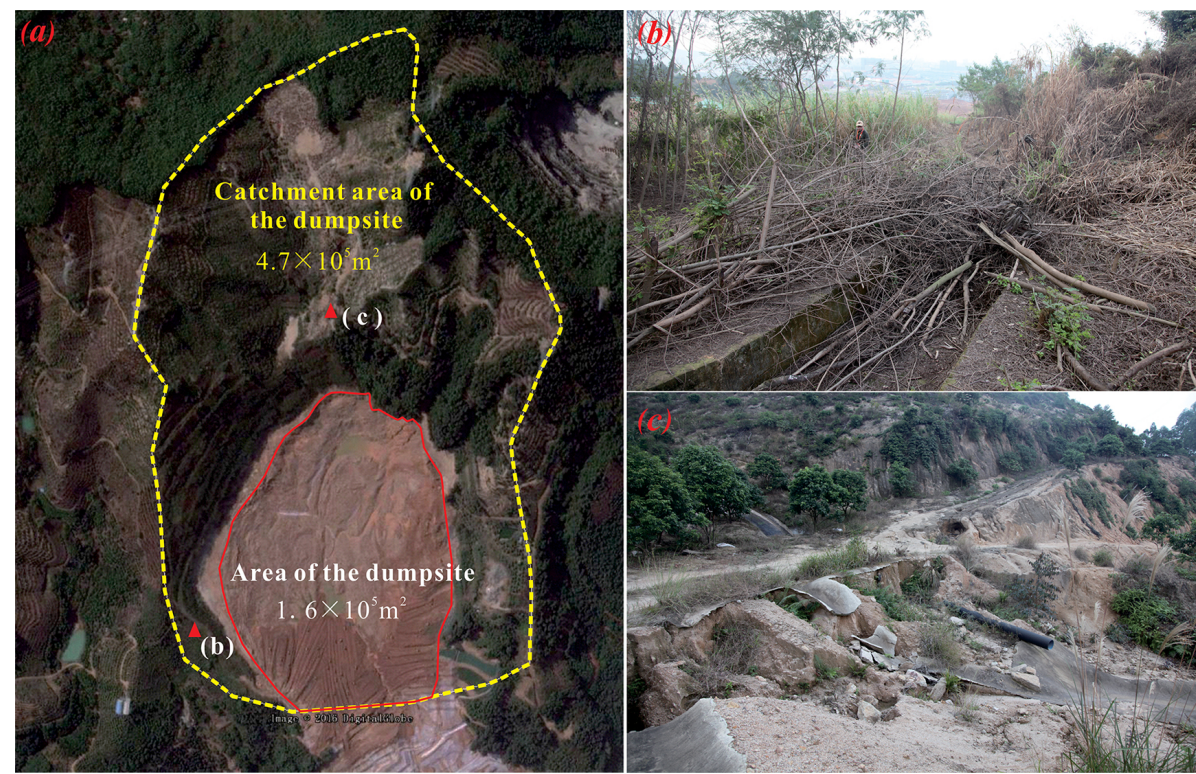

Figure 5. (a) Overview of the catchment area (Google Earth image); (b) the surrounding peripheral drainage channel of the dumpsite was abandoned; (c) damaged drainage pipes were not repaired and failed to divert surface runoff into the peripheral drainage channel. Surface runoff concentrated in the waste filling.
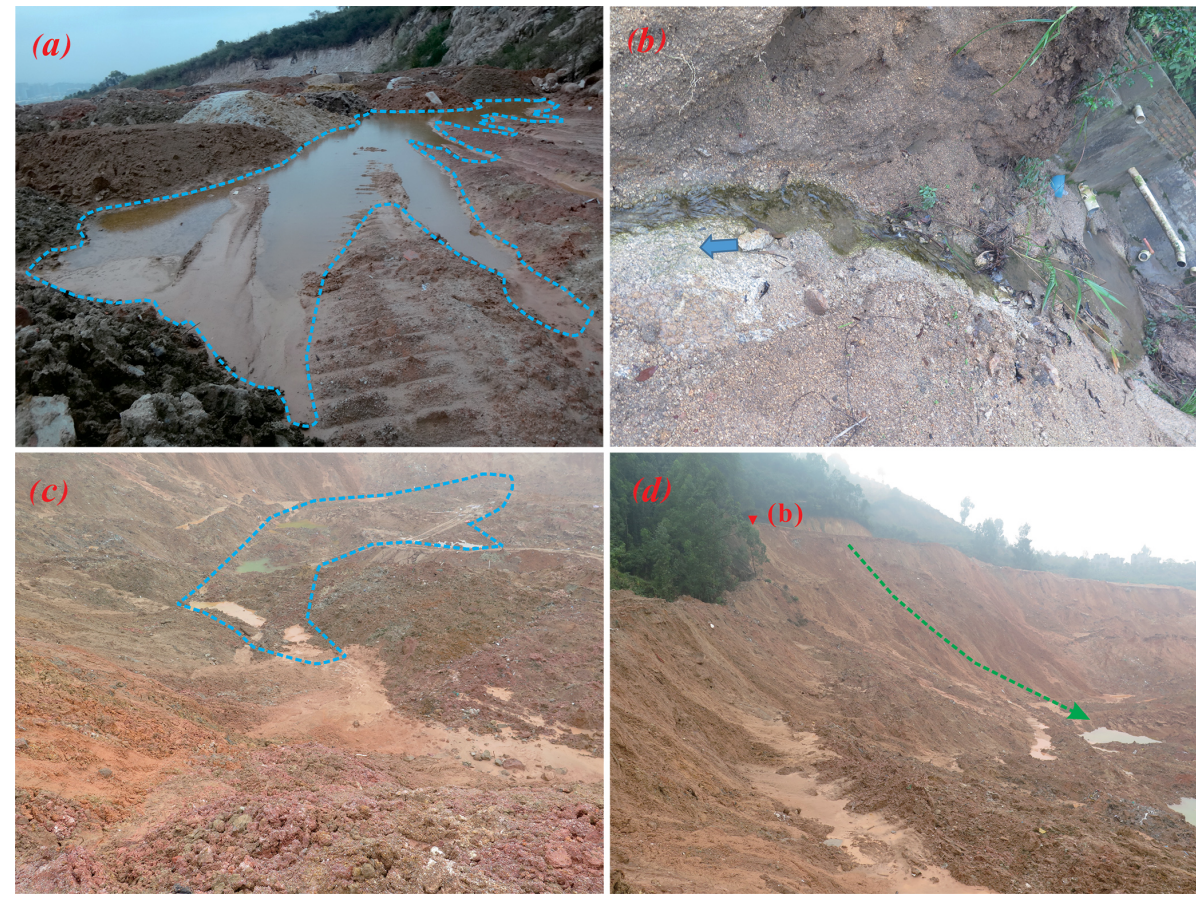

Figure 6. (a) Groundwater overflow in the rock fissures near the flowslide crown; (b) water accumulation in the flowslide crown; (c) water accumulation in the source area; (d) surface runoff and infiltration contributed to groundwater seepage.

of waste was dumped in the pit, with four slope benches built at the exit of the pit (Fig. 7e). A total of eight slope benches were completed with surface drainage channels installed on the hillslope, and the ninth bench was almost completed 2 days before the flowslide. The volume of the waste increased significantly with the first and second bench completed in late 2014, and the third to fourth benches were constructed by January 2015 (Fig. 7f). The fifth and sixth benches were completed in September 2015, while the seventh and eighth benches were completed in December 2015. 

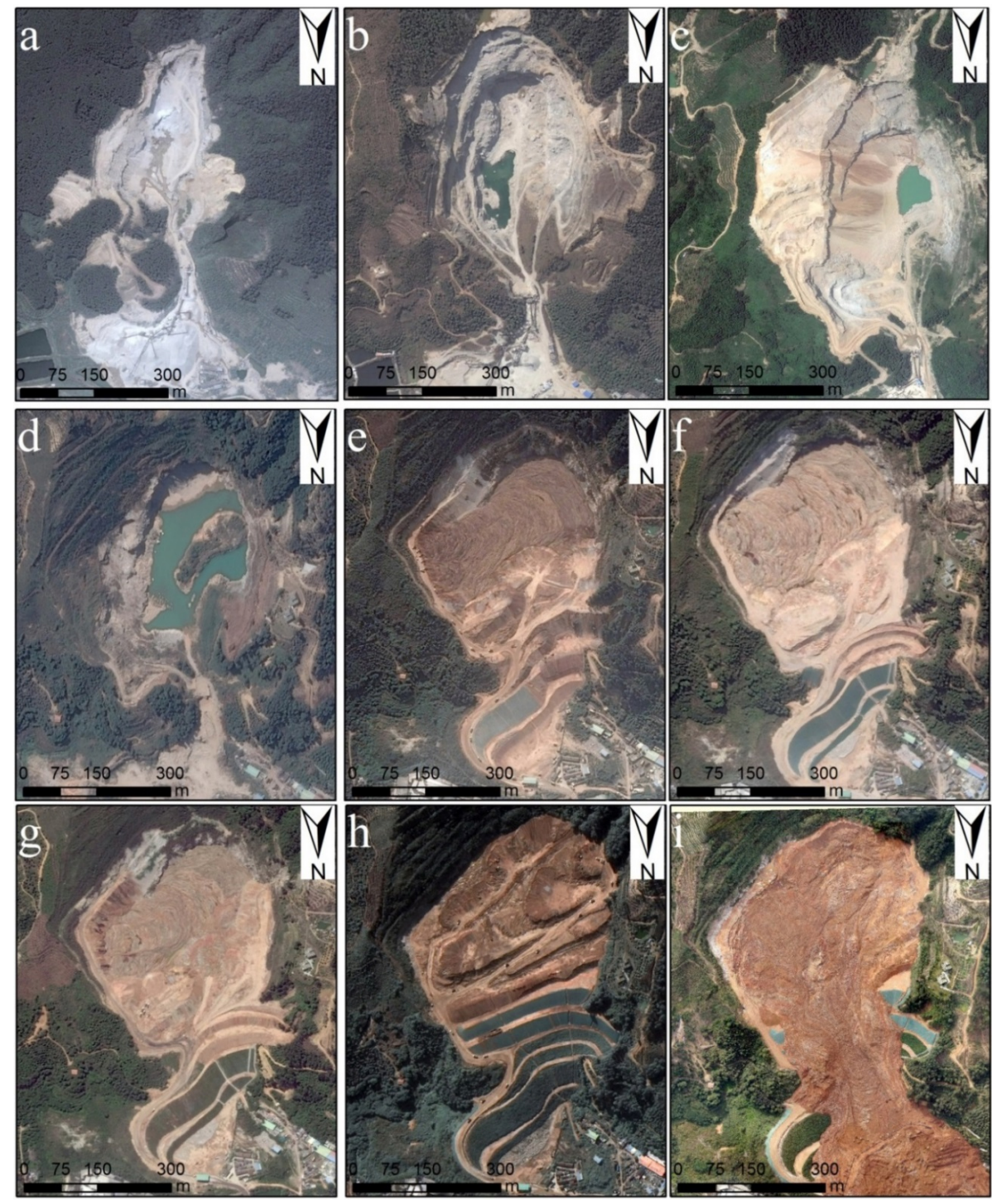

Figure 7. Multi-temporal remote-sensing images of the study area. (a) 31 August 2002; (b) 20 February 2008; (c) 30 August 2010; (d) 25 November 2013; (e) 17 November 2014; (f) 23 January2015; (g) 14 April 2015; (h) Pléiades (18 December 2015); (f) aerial (23 December 2015). Panels (a) to (g) were obtained from Google Earth. A service road was excavated at the exit of the quarry with a width of nearly $70 \mathrm{~m}$ (see panels $\mathbf{a}, \mathbf{b}, \mathbf{c}$, and $\mathbf{d}$ ).

The rapid accumulation and the total volume of the waste filling received some attention before failure. An environmental assessment provided by a third-party consulting firm warned about the erosion at the site and its influence on the slope stability in January 2015 (Zou, 2016). The disposal activity was ceased for a while, as discerned from no trucks being seen in the image (Fig. 7f), which was verified by interviewing the local inhabitants. The disposal activity was resumed in or before April 2015, and the fourth bench was completed by then (Fig. $7 \mathrm{~g}$ ). By comparing Fig. $7 \mathrm{~g}$ and Fig. $7 \mathrm{~h}$, significant modifications on the landform occurred with a major increase in the volume of the waste filling, wherein landfill was close to the crest of the pit. The fill- ing appeared flattened, and the disposal activity was intense as more than 20 trucks are found in Fig. 7h. The thickness of the waste filling was around $90 \mathrm{~m}$ with an estimated volume of $6.3 \times 10^{6} \mathrm{~m}^{3}$ by extracting the difference of the pre- and post-filling DEMs (Fig. 8a). The pre-filling DEM was constructed by using the topographical map of the study area that was included in the design of the dumpsite. The pre-failure DEM was georeferenced by using the post-failure DEMs, which assumed that the coordinates of the objects located outside the landslide deposit area remained the same and thus estimated the volume of the waste filling. 
Table 1. Geometric parameters of the flowslide (length and width).

\begin{tabular}{lrrrrrrrrr}
\hline Parameter & $\begin{array}{r}L \\
(\mathrm{~m})\end{array}$ & $\begin{array}{r}H \\
(\mathrm{~m})\end{array}$ & $\begin{array}{r}W_{1} \\
(\mathrm{~m})\end{array}$ & $\begin{array}{r}W_{2} \\
(\mathrm{~m})\end{array}$ & $\begin{array}{r}W_{3-1} \\
(\mathrm{~m})\end{array}$ & $\begin{array}{r}W_{3-2} \\
(\mathrm{~m})\end{array}$ & $\begin{array}{r}W_{4-1} \\
(\mathrm{~m})\end{array}$ & $\begin{array}{r}W_{4-2} \\
(\mathrm{~m})\end{array}$ & $\begin{array}{r}W_{5} \\
(\mathrm{~m})\end{array}$ \\
\hline Value & 1204.67 & 111.31 & 212.5 & 399.32 & 218.31 & 149.38 & 217.71 & 64.63 & 592.25 \\
\hline
\end{tabular}

Table 2. Geometric parameters of the flowslide (angle).

\begin{tabular}{|c|c|c|c|c|c|c|c|c|c|}
\hline Parameter & $\begin{array}{l}\Phi_{1} \\
\left(^{\circ}\right)\end{array}$ & $\begin{array}{l}\Phi_{2} \\
\left(^{\circ}\right)\end{array}$ & $\begin{array}{l}\Phi_{3} \\
\left(^{\circ}\right)\end{array}$ & $\begin{array}{l}\Phi_{4} \\
\left(^{\circ}\right)\end{array}$ & $\begin{array}{l}\Phi_{5} \\
\left(^{\circ}\right)\end{array}$ & $\begin{array}{l}\Phi_{6} \\
\left(^{\circ}\right)\end{array}$ & $\begin{array}{l}\Phi_{7} \\
\left(^{\circ}\right)\end{array}$ & $K$ & $\begin{array}{r}S \\
\left(\mathrm{~m}^{2}\right)\end{array}$ \\
\hline Value & 5.28 & 28.06 & 1.2 & 7.62 & 11.36 & 3.08 & 1.36 & 0.32 & 398619.6 \\
\hline
\end{tabular}

Table 3. Geometric parameters of the flowslide (area and thickness).

\begin{tabular}{lll}
\hline Parameter & Area A & Area B \\
\hline$S\left(\mathrm{~m}^{2}\right)$ & $11.35 \times 10^{4}$ & $28.51 \times 10^{4}$ \\
$V\left(\mathrm{~m}^{3}\right)$ & $3.95 \times 10^{6}$ (remaining) & $2.34 \times 10^{6}$ \\
$T_{\max }(\mathrm{m})$ & 41.51 & 18.82 \\
$T_{\text {ave }}(\mathrm{m})$ & 20.49 & 8.21 \\
\hline
\end{tabular}

\section{Flowslide characteristics}

The flowslide area can be divided into the source area and the flow-accumulation area as shown in Fig. 9. The source area was the abandoned quarry pit. The mass slid in the direction of $340^{\circ}$ with a maximum traveling distance of $1203 \mathrm{~m}$ (Fig. 10). The maximum thickness of the remaining material in the source area was $41.51 \mathrm{~m}$ with an average of $20.5 \mathrm{~m}$ (Figs. 9 and 10). The maximum deposit thickness in the flowaccumulation area was $18.2 \mathrm{~m}$ with an average of $8.21 \mathrm{~m}$ (Fig. 8b). The geometry of a flowslide can be expressed in length $(L)$, height $(H)$, width $(W)$, and area $(S)$ (Legros, 2002; Scheidegger, 1973). The geometric parameters are indicated in the simplified flowslide geometry in Fig. 11, with values tabulated in Tables 1,2, and 3 .

\subsection{Source area}

The source area of the flowslide is the quarry pit with a length $\left(L_{1+2+3}\right)$ of $540.30 \mathrm{~m}$ and a width $\left(W_{2}\right)$ of $399.32 \mathrm{~m}$. The area $\left(S_{\mathrm{A}}\right)$ is $11.35 \times 10^{4} \mathrm{~m}^{2}$, and the height $\left(H_{1+2+3}\right)$ was $68.5 \mathrm{~m}$ with an apparent $\operatorname{dip}\left(\Phi_{4}\right)$ of $7.62^{\circ}$ (Fig. 12 and Table 1). The volume of the mobilized material was $2.32 \times 10^{6} \mathrm{~m}^{3}$, with the remaining volume being $3.95 \times 10^{6} \mathrm{~m}^{3}$. The maximum thickness $\left(T_{\mathrm{A}-\max }\right)$ was $41.5 \mathrm{~m}$ with an average $\left(T_{\mathrm{A} \text {-ave }}\right)$ of $20.5 \mathrm{~m}$. The west side of main scarp has a steep slope gradient with a mild gradient on the east side. The height of the steep scarp was $25-47 \mathrm{~m}$, while the height of the mild scarp was $10-20 \mathrm{~m}$. The geological cross section (profile line 2-2') is shown in Fig. 12c. An overview of the source area and surface cracks is shown in Fig. 12a and b, respectively.

Pore-water pressure increases as rainwater and groundwater infiltrate the dumpsite. The lack of drainage resulted in waste filling saturation in the basal zone of the dumpsite, which appeared as the sliding surface of the flowslide (Fig. 12a). A large amount of silty soil was observed in the source area. The water content of the remaining materials in the source area is $17.3-42.4 \%$ (six sampling locations). The materials on both sides of the source area were mobilized due to a debuttressing effect as the waste filling in the lower portion of the dumpsite slid and, in consequence, caused the collapse of the dumpsite. A step-like steep scarp was formed on the west side of main scarp, with tensile cracks having developed on the rear edge as well as on both sides of the scarp.

The presence of the aforementioned rock ridges formed unfavorable topography for the retaining slope stability, as it promoted a narrow gully for groundwater flow and concentration (Figs. 7c and 9). As a result of the retaining slope failure, a large opening was formed at the elevation of $73.7 \mathrm{~m}$ (between the front edge of the steep scarp and the rear edge of the flow-accumulation area) as shown in Figs. 9, 10, and 12a. The displaced material was stratified in the middle part of the flow-accumulation area during the high-speed sliding. The shape of the failed retaining slope was half-elliptic-like with a width $\left(W_{4-1}\right)$ of $217.7 \mathrm{~m}$ and a height $\left(H_{\mathrm{b}}\right)$ of $27.5 \mathrm{~m}$ (Fig. 13a and c).

\subsection{Flow-accumulation area}

The fan-shaped flow-accumulation area mantled the failed retaining slope of the dumpsite as well as a large part of the industrial park (Fig. 12a). The water content of the displaced material was $32.1-37.2 \%$ (three sampling locations). The original slope gradient of the industrial park $(\Phi)$ was $1.36^{\circ}$ along the profile line 1-1' (Fig. 12 and Table 1). The area located immediately downstream of the dumpsite was relatively flat with no major construction except a pond (approximately $3600 \mathrm{~m}^{2}$ ) and a channel (width: $7 \mathrm{~m}$; length: $130 \mathrm{~m}$ ) 

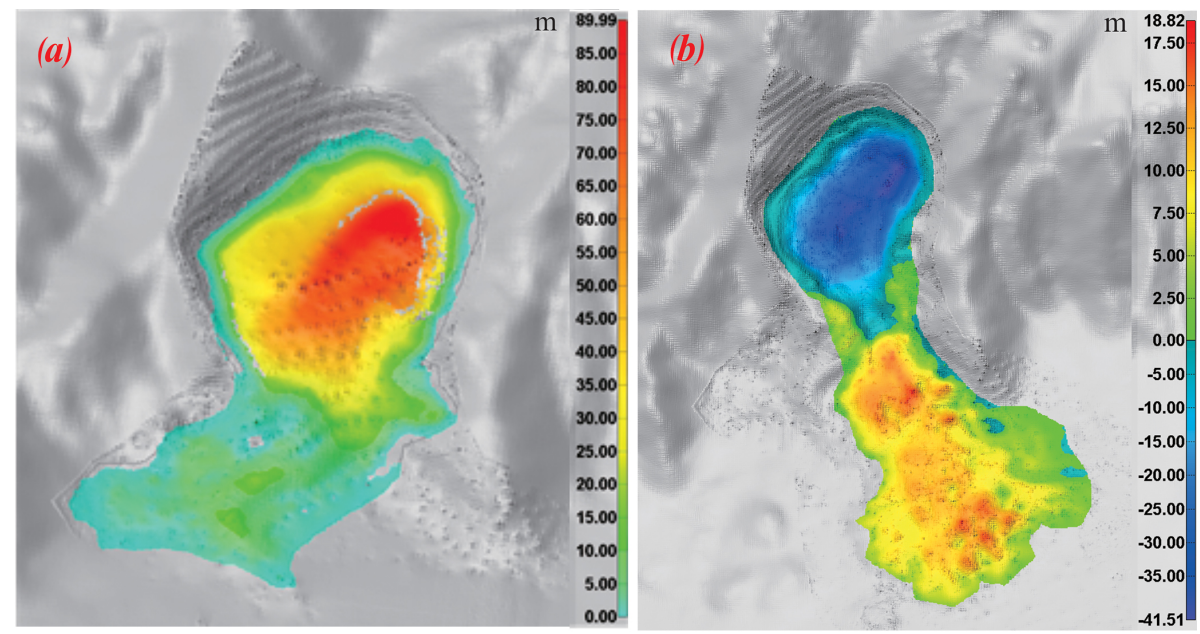

Figure 8. (a) The thickness distribution of the dumpsite based on the pre-/post-disposal DEMs; (b) the elevation variations of the dumpsite estimated between the pre- and post-failure DEMs.

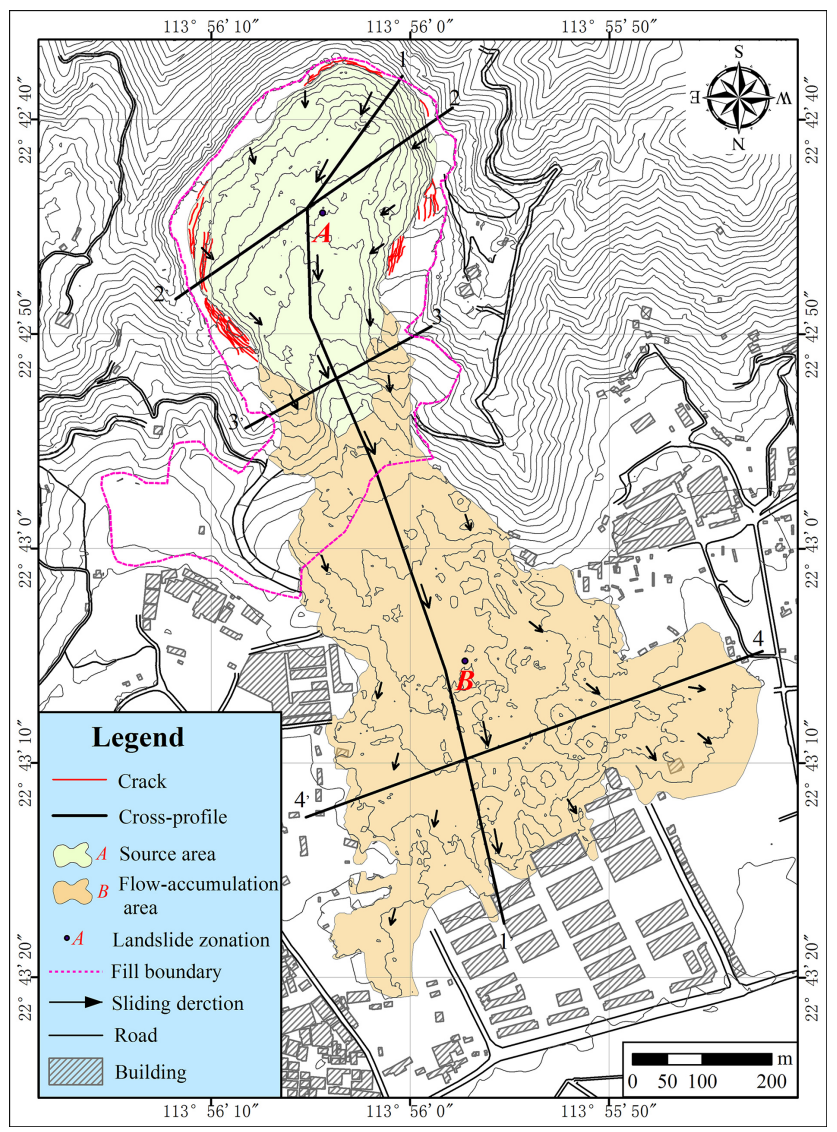

Figure 9. The topographic map of the flowslide.

as shown in Fig. 1. Most of the industrial structures were located on the east, west, and north sides of the pond (Figs. 1 and 9), which created an ideal flow path for the flowslide without obstructions. The failure of the retaining slope re- sulted in an opening for the mass movement, which subsequently destroyed downstream buildings (Figs. 14 and 15).

\section{Back analyses of the flowslide}

\subsection{Flowslide movement}

The high sliding velocity and long runout distance of the flowslide may be related to a more diffuse failure due to liquefaction near the base of the slope. Evidence of localized liquefaction can be found at several locations (Fig. 16). Empirical correlation was used to back-calculate the flowslide travel velocity with its geometrical characteristics. Laboratory tests and back analyses were performed to better understand the failure process.

The source area of the flowslide was at an elevation of $142 \mathrm{~m}$, and the horizontal runout distance $(L)$ was approximately $1203 \mathrm{~m}$ with an elevation difference $(H)$ of $111 \mathrm{~m}$ (Fig. 11). The velocity of a high-speed landslide can be estimated by $v=\sqrt{2 g \times(H-f \times L)}$ (Scheidegger, 1973), where $v$ is the sliding velocity $\left(\mathrm{m} \mathrm{s}^{-1}\right), g$ is the gravitational acceleration $\left(\mathrm{m} \mathrm{s}^{-12}\right)$, and $H$ and $L$ are the elevation difference and horizontal distance $(\mathrm{m})$ between the crown and toe of the flowslide, respectively. The equivalent friction coefficient, $f$, is the ratio of height to runout distance of the flowslide $(f=0.092)$. The travel velocity was backcalculated and is presented in Fig. 17.

Based on the back-calculated velocity profile, two sharp increases were identified, including the initiation of the waste filling movement from the steep scarp and the acceleration of the flowslide exiting the dumpsite. The travel velocity was $15.17 \mathrm{~m} \mathrm{~s}^{-1}$ as waste filling reached the bottom of the steep scarp. The velocity of the displaced material gradually decreased to around $13 \mathrm{~m} \mathrm{~s}^{-1}$ before accelerating to the maximum velocity of $25.15 \mathrm{~m} \mathrm{~s}^{-1}$ as it reached the opening of 


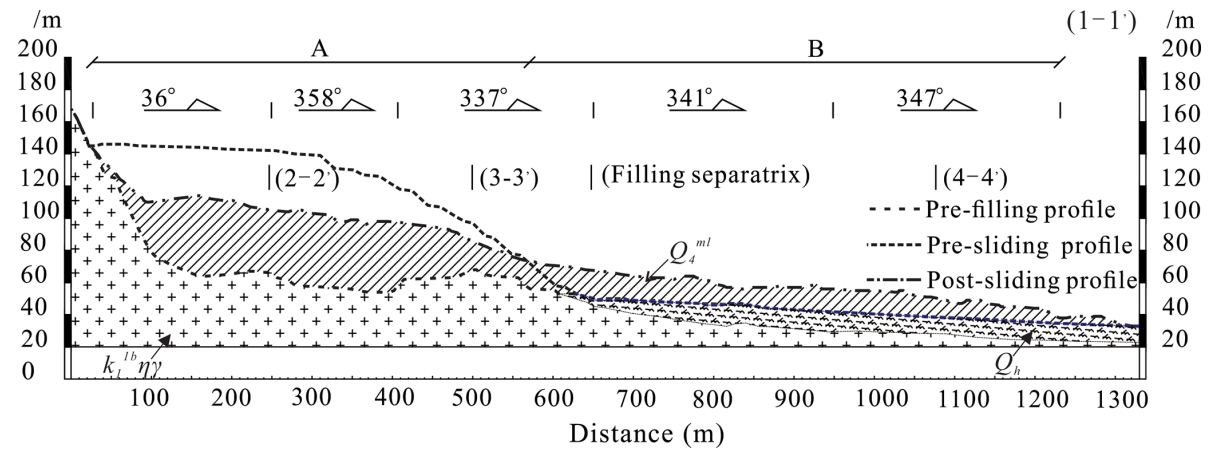

Figure 10. The geological and topographical cross section (profile line 1-1').

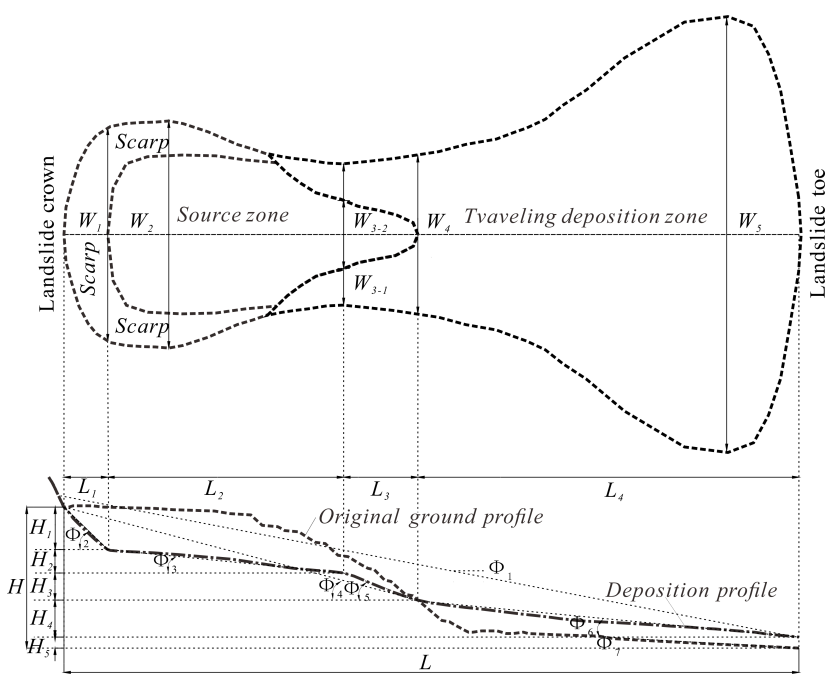

Figure 11. Simplified illustration of the flowslide geometry. $L$ : runout distance; $H$ : elevation; $W_{1}$ : scarp width; $W_{2}$ : max width of the source area; $W_{3}$ : frontal width of the source area; $W_{4}$ : width of the shear crack; $W_{5}$ : max width of the flow-accumulation area; $L_{1}$ : horizontal length of the scarp; $L_{2}$ : horizontal length of the mild slope; $L_{3}$ : horizontal length of the steep slope; $L_{4}$ : horizontal length of the flow-accumulation area; $H_{1}$ : height of the scarp; $H_{2}$ : height of the mild slope; $H_{3}$ : height of the steep slope; $H_{4}$ : height of the flow-accumulation area; $H_{5}$ : thickness of the toe of the flowslide; $\Phi_{1}$ : extension angle; $\Phi_{2}$ : slope gradient of the scarp; $\Phi_{3}$ : mild slope gradient; $\Phi_{4}$ : slope gradient of the source area; $\Phi_{5}$ : steep slope gradient; $\Phi_{6}$ : slope gradient of the flow-accumulation area; $\Phi_{7}$ : slope gradient of the foundation area.

the quarry. The second sharp acceleration was followed by the rapid dissipation of kinematic energy and reduction in travel velocity after encountering obstructions in the flowaccumulation area. It was estimated that the velocity was reduced to $15.68 \mathrm{~m} \mathrm{~s}^{-1}$ when it made contact with downstream buildings. The geometry and velocity profile exhibited clear characteristics associated with high-speed longrunout flowslides.

\subsection{Back calculation}

Basic material properties were obtained from in situ and laboratory tests. The dry density of the waste filling was 1.25 $1.48 \mathrm{~g} \mathrm{~cm}^{-3}$ with a void ratio of $0.83-1.31$. Standard compaction tests suggested an optimal water content of $15.3 \%$ with a highest dry density of $1.79 \mathrm{~g} \mathrm{~cm}^{-3}$. The surface of the filling was in a loose state with compaction of $69.8-82.7 \%$. Based on the undrained shear test, the $c$ and $\phi$ of the filling were $4.7 \mathrm{kPa}$ and $31.9^{\circ}$, respectively, so the friction angle was considerably higher than the gradient of the retaining slope (ave. $20^{\circ}$ ). No strain softening was observed in the saturated specimen under triaxial tests.

Numerical simulation for diffuse failure involves liquefaction, and post-failure propagation is challenging (Take and Beddoe, 2014); the conventional LEM is typically not applicable for analyzing the propagation of a landslide originating from a diffuse failure induced by liquefaction (Cascini et al., 2009, 2013). Back calculations were performed by using SLOPE/W (GEO-SLOPE International Ltd., 2005) with Morgenstern-Prince limit equilibrium analysis under the assumption that a fully saturated basal zone formed in the dumpsite before failure. The back analyses using the LEM method typically set the factor of safety (FoS) to unity to back-calculate the mobilized strength. The final sliding surface and a hypothetic groundwater level were added to determine the shear strength in an iterative approach with $\rho_{\text {dry }}=$ $1.65 \mathrm{~g} \mathrm{~cm}^{-3}$ for the filling (Fig. 18); however the backcalculated friction angle was significantly less than the experimental finding.

The implausible mobilized strength shows that back analyses using LEM is not applicable to this flowslide, as the failure may involve liquefaction with subsequent progressive failure and post-failure propagation. Notwithstanding the complex progressive mechanism and over-simplified force equilibrium method, the misleading results of the back analyses can be ascribed to the misuse of static pre-shearing porewater pressure with measured final sliding surface. Such an erroneous back-analysis strategy was discussed in detail by Take et al. (2004). It was postulated that the failure may be 


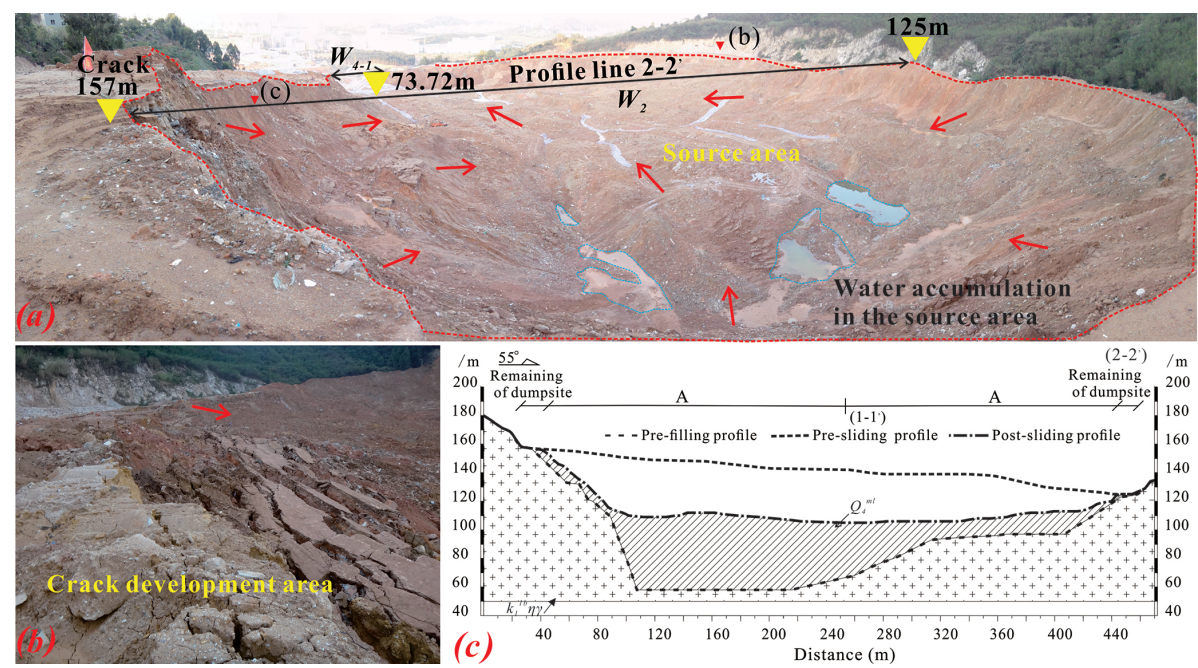

Figure 12. (a) An overview of the source area (image taken at the flowslide crown facing north). A large opening ( $\left.W_{4-1}\right)$ formed due to the failure of the retaining slope (the exit of the original quarry pit), which provided passage for the flowslide and permitted rapid release of kinematic energy. (b) Surface cracks developed due to unloading near the crest and the flanks of the flowslide. (c) The geological cross section (profile line 2-2') of the source area.

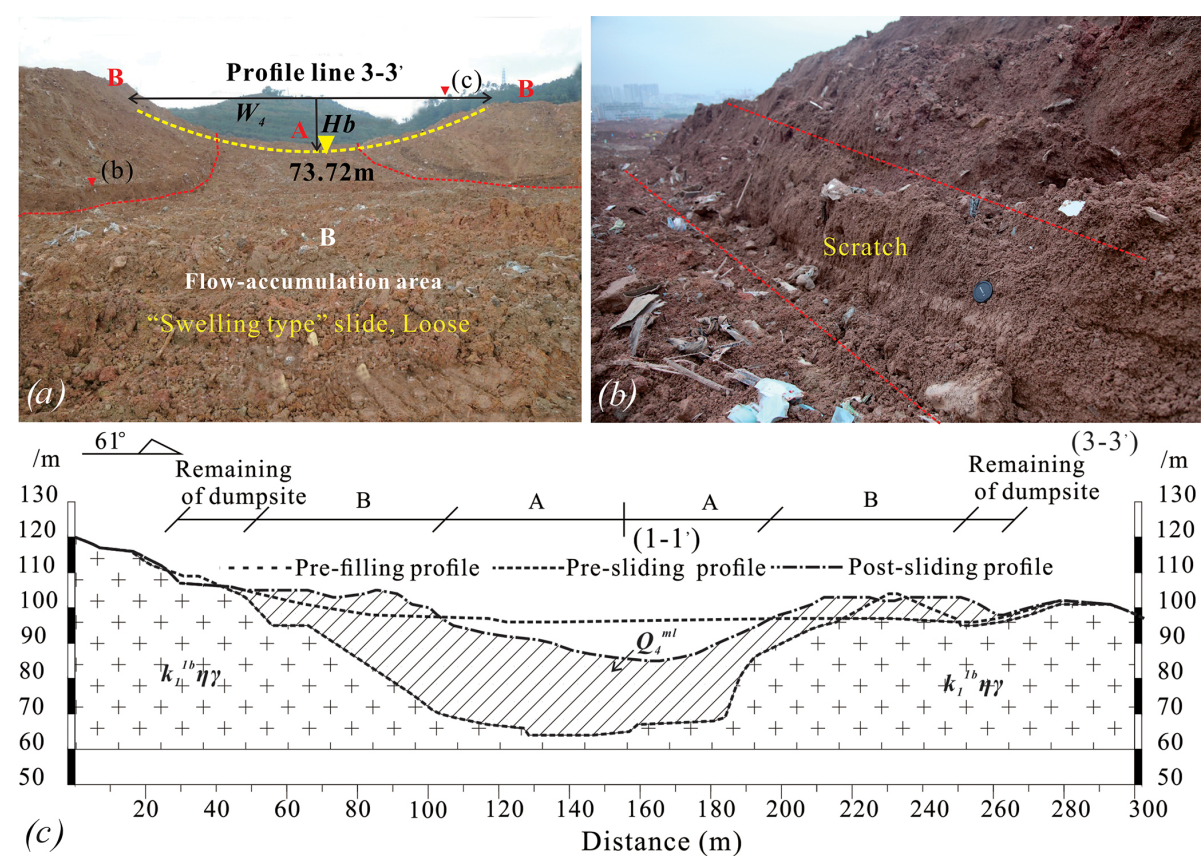

Figure 13. (a) The half-elliptic-like opening of the failed retaining slope; (b) details on the scratch caused by mass movement; (c) geological cross section (profile line 3-3') of the failed retaining slope located at the original quarry pit between the two rock ridges.

initiated at a relatively shallow depth near the base of the slope as a result of static liquefaction, followed by progressive backward mobilization of the fillings in the dumpsite.

The exact reason for excess pore-water pressure remains unclear, but it was a key factor in causing the failure, which was also confirmed by the simulation attempts on the flowslide by Ouyang et al. (2016). The excess pore-water pressure in the flowslide may be induced by (1) the rapid surcharge on the dumpsite while pore water cannot dissipate sufficiently fast and/or (2) the waste filling being loosely packed with large pores in the mesco-structure, and the collapse of the structure leading to the shrinkage of pores, resulting in excess pore-water pressure. Since the permeability of the waste filling was considerably low, it may result in saturation in the basal zone. As no clear drainage passage 

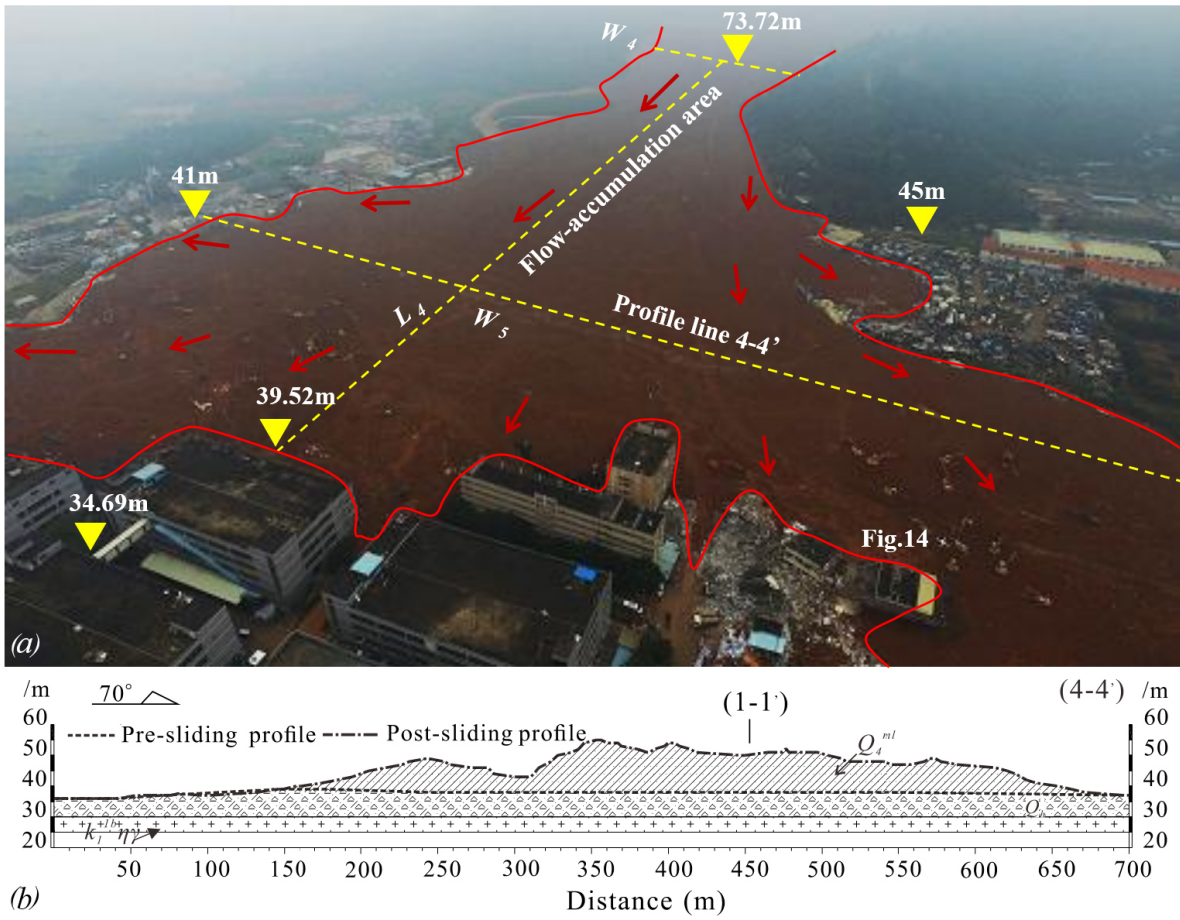

Figure 14. (a) Overview of the flow-accumulation area with elevations (China News Agency); (b) geological cross section (profile line 4-4') of the flow-accumulation area. The length $\left(L_{4}\right)$ was $664.4 \mathrm{~m}$, and the width $\left(W_{3}\right)$ was $218.3 \mathrm{~m}$, with the width of the front edge $\left(W_{5}\right)$ being $592.3 \mathrm{~m}$. The area was $28.51 \times 10^{4} \mathrm{~m}^{2}$, and the elevation difference $\left(H_{4}\right)$ was $35.7 \mathrm{~m}$ with an apparent dip $\left(\Phi_{6}\right)$ of $3.08^{\circ}$. The average thickness was $8.21 \mathrm{~m}$ with the maximum thickness of $18.82 \mathrm{~m}$ (Fig. 12c, Table 1, and Table 3).

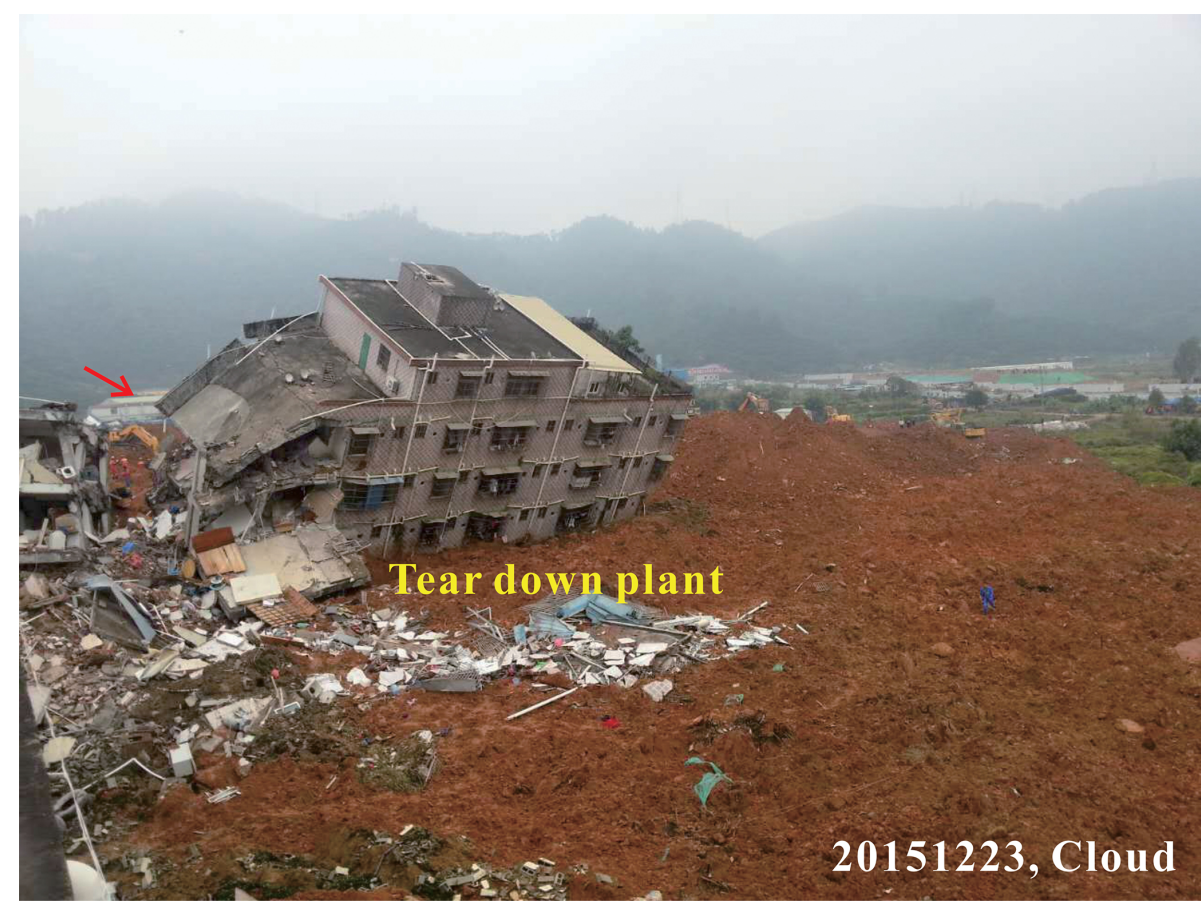

Figure 15. The damage of buildings in the industrial park. 

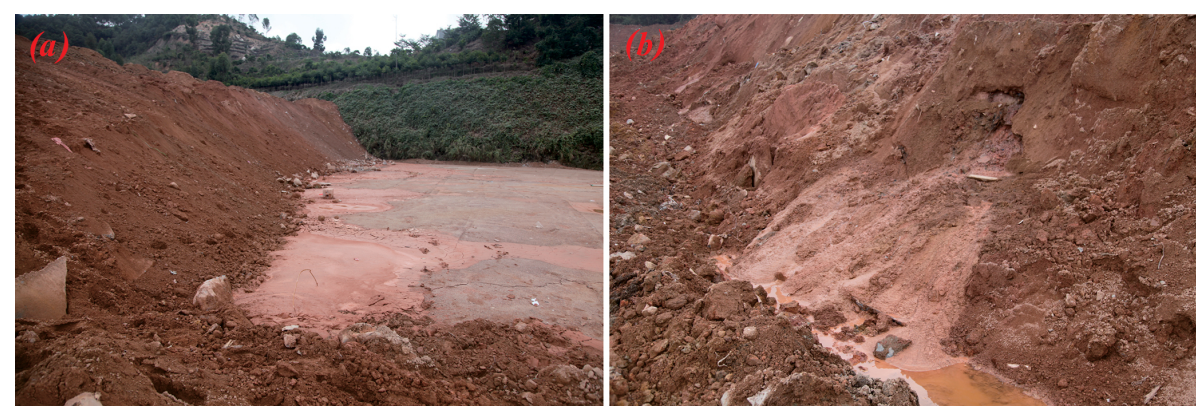

Figure 16. Evidence of liquefaction near the opening of the failed slope.

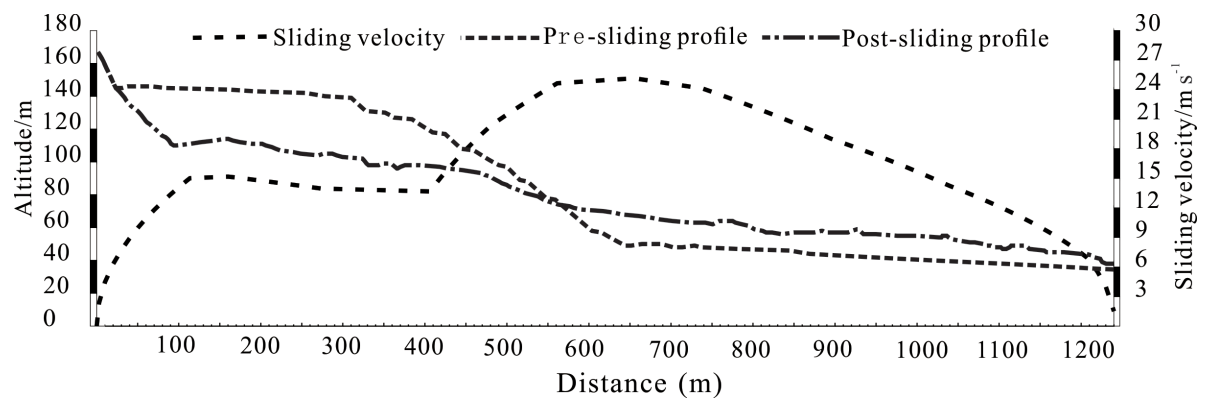

Figure 17. The estimated travel velocity profile along profile line 1-1' with pre-/post-sliding landform.

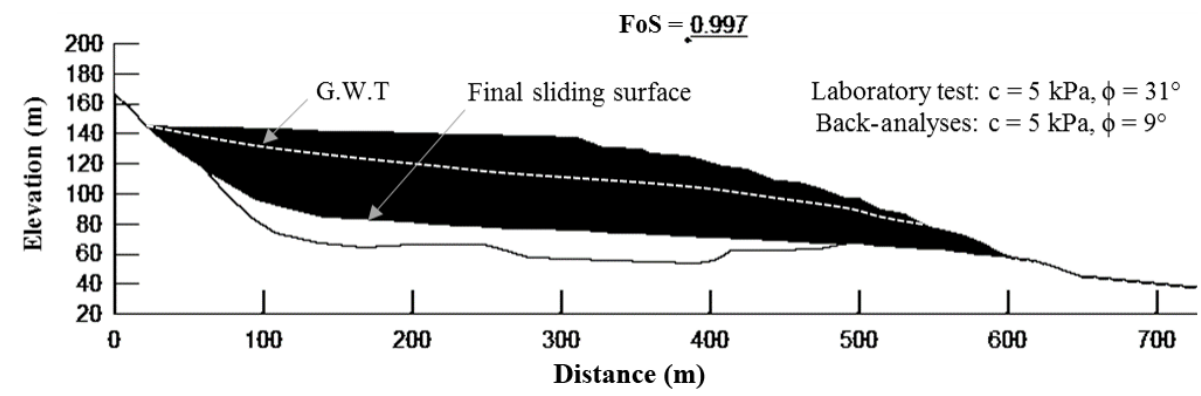

Figure 18. Back-calculated mobilized strength by using 2-D numerical model with LEM.

was found in the filling, the displaced material may remain undrained "at failure".

\section{Conclusions}

The Hongao dumpsite failure is of direct interest to the scientific community due to its complex progressive failure mechanism and significant societal impact. The failure clearly emphasized the importance of MSW management, including (1) strict enforcements on the dumping activities based on the design capacity and (2) the maintenance of a drainage system with field monitoring of the pore-water pressure. The flowslide was investigated here to better understand its characteristics and mechanism. The flowslide is divided into the source area and the flow-accumulation area. The volume of the source area was $2.32 \times 10^{4} \mathrm{~m}^{3}$ with an average thickness of $20.5 \mathrm{~m}(\max 41.5 \mathrm{~m})$. The volume of the fan-shaped flowaccumulating area was $2.34 \times 10^{6} \mathrm{~m}^{3}$ with an average thickness of $8.2 \mathrm{~m}(\max 18.8 \mathrm{~m})$. The maximum travel velocity of the flowslide was estimated as $25.15 \mathrm{~m} \mathrm{~s}^{-1}$ at the opening of the dumpsite and reduced to $15.68 \mathrm{~m} \mathrm{~s}^{-1}$ as it reached the industrial park and ceased moving due to the obstruction of buildings.

The flowslide was characterized by high speed and long runout distance, which may be related to (1) the height difference of $124 \mathrm{~m}$ between the crown and toe storing sufficient potential energy for a high-speed and long-runout flowslide, and (2) the low permeability and lack of drainage in the dumpsite with impermeable bedrock resulting in groundwater stagnation and thus high pore-water pressure. The failure of the retaining slope between the rock ridges formed a narrow opening for the flowslide, which facilitated the sudden 
release of kinematic energy generating high travel velocity and long runout distance.

The failure mechanism remains unclear, yet it was clear that a more diffuse failure occurred with liquefaction and post-failure propagation of the flowslide. The inapplicability of the LEM demonstrated the complexity of the mechanism by yielding erroneous mobilized strength, which also indicates the predicament of simulating liquefaction-induced slope failures with conventional numerical approaches. The cause(s) of excess pore-water pressure is not clear, but the poorly regulated disposal activities in addition to the ingress of rainwater and high pore-water pressure played important roles in the deformation of the dumpsite. Although the flowslide destruction process was fast with excessive deposits, it is postulated that signs of deformation may have already appeared in the study site but not been discovered due to the absence of field monitoring. Further analysis is ongoing at SKLGP to assess the cause(s) involved in generating excess pore-water pressure.

\section{Data availability}

Datasets of rainfall records, grain size distribution, and undrained shear test are available online (doi:10.13140/RG.2.2.10594.94400, Xu et al., 2017a). The raw data of the geological cross-section of the master profile line is available online (doi:10.13140/RG.2.2.24016.71681, $\mathrm{Xu}$ et al., 2017b). The multi-temporal remote-sensing images are available from Google Earth, and the Pléiades image is commercially available. The aerial images with embedded coordinates are regulated by the government and are therefore not publicly available. Any additional processed data files are available on request from the first or corresponding author.

Competing interests. The authors declare that they have no conflict of interest.

Acknowledgements. Authors are indebted to J. David Frost for his constant support in the collaboration. The reviews and suggestions from W. P. Wang, Y. Huang, and two anonymous referees are greatly appreciated. The work was financially supported by the National Natural Science Foundation (NSFC, grant no. 41521002) and the National State Key 973 Project (grant no. 2014CB744703) from the Ministry of Science and Technology of the People's Republic of China.

Edited by: T. Glade

Reviewed by: W. P. Wang, Y. Huang, and two anonymous referees

\section{References}

Blight, G.: Slope failures in municipal solid waste dumps and landfills: a review, Waste Manag. Res., 26, 448-463, doi:10.1177/0734242X07087975, 2008.

Blight, G. E. and Fourie, A. B.: Catastrophe revisited-disastrous flow failures of mine and municipal solid waste, Geotech. Geol. Eng., 23, 219-248, 2005.

Brunner, P. H. and Fellner, J.: Setting priorities for waste management strategies in developing countries, Waste Manag. Res., 25, 234-240, doi:10.1177/0734242X07078296, 2007.

Cascini, L., Cuomo, S., Pastor, M., and Sorbino, G.: Modeling of rainfall-induced shallow landslides of the flow-type, J. Geotech. Geoenvironmental Eng., 136, 85-98, 2009.

Cascini, L., Cuomo, S., Pastor, M., and Sacco, C.: Modelling the post-failure stage of rainfall-induced landslides of the flow type, Can. Geotech. J., 50, 924-934, 2013.

Chang, M.: A 3D slope stability analysis method assuming parallel lines of intersection and differential straining of block contacts, Can. Geotech. J., 39, 799-811, doi:10.1139/t02-020, 2002.

Chang, M.: Three-dimensional stability analysis of the Kettleman Hills landfill slope failure based on observed sliding-block mechanism, Comput. Geotech., 32, 587-599, 2005.

Chugh, A. K., Stark, T. D., and DeJong, K. A.: Reanalysis of a municipal landfill slope failure near Cincinnati, Ohio, USA, Can. Geotech. J., 44, 33-53, doi:10.1139/t06-089, 2007.

Dai, Z., Huang, Y., Jiang, F., and Huang, M.: Modeling the flow behavior of a simulated municipal solid waste, Bull. Eng. Geol. Environ., 75, 275-291, doi:10.1007/s10064-015-0735-8, 2016.

Eid, H. T., Stark, T. D., Evans, W. D., and Sherry, P. E.: Municipal solid waste slope failure. I: Waste and foundation soil properties, J. Geotech. Geoenvironmental Eng., 126, 397-407, 2000.

GEO-SLOPE International Ltd.: SLOPE/W, Slope stability analysis, GEO-SLOPE International Ltd., Calgary, Alberta, Canada, 2005.

Huang, Y. and Cheng, H.: A simplified analytical model for runout prediction of flow slides in municipal solid waste landfills, Landslides, 14, 99-107, doi:10.1007/s10346-016-0688-4, 2017.

Huang, Y. and Zhu, C.: Simulation of flow slides in municipal solid waste dumps using a modified MPS method, Nat. Hazards, 74, 491-508, doi:10.1007/s11069-014-1194-4, 2014.

Huang, Y., Dai, Z., Zhang, W., and Huang, M.: SPHbased numerical simulations of flow slides in municipal solid waste landfills., Waste Manag. Res., 31, 256-264, doi:10.1177/0734242X12470205, 2013.

Huvaj-Sarihan, N. and Stark, T. D.: Back-Analyses of Landfill Slope Failures, 6th Int. Conf. Case Hist. Geotech. Eng., 2, 1-7, 2008.

Kjeldsen, P. and Fischer, E. V: Landfill gas migration - field investigations at Skellingsted landfill, Denmark, Waste Manag. Res., 13, 467-484, 1995.

Kocasoy, G. and Curi, K.: The Ümraniye-Hekimbaşi open dump accident, Waste Manag. Res., 13, 305-314, 1995.

Lavigne, F., Wassmer, P., Gomez, C., Davies, T. A., Sri Hadmoko, D., Iskandarsyah, T. Y. W. M., Gaillard, J., Fort, M., Texier, P., Boun Heng, M., and Pratomo, I.: The 21 February 2005 , catastrophic waste avalanche at Leuwigajah dumpsite, Bandung, Indonesia, Geoenvironmental Disasters, 1, 1-12, doi:10.1186/s40677-014-0010-5, 2014. 
Legros, F.: The mobility of long-runout landslides, Eng. Geol., 63, 301-331, available at: http://www.sciencedirect.com/science/ article/pii/S0013795201000904, (last access: 25 June 2014), 2002.

Merry, S. M., Kavazanjian Jr., E., and Fritz, W. U.: Reconnaissance of the July 10, 2000, Payatas landfill failure, J. Perform. Constr. Facil., 19, 100-107, 2005.

Mitchell, J. K., Seed, R. B., and Seed, H. B.: Kettleman Hills waste landfill slope failure. I: Liner-system properties, J. Geotech. Eng., 116, 647-668, doi:10.1061/(ASCE)07339410(1990)116:4(647), 1990.

Ouyang, C., Zhou, K., Xu, Q., Yin, J., Peng, D., Wang, D., and Li, W.: Dynamic analysis and numerical modeling of the 2015 catastrophic landslide of the construction waste landfill at Guangming, Shenzhen, China, Landslides, 2016 (April), doi:10.1007/s10346016-0764-9, 2016.

Scheidegger, A. E.: On the prediction of the reach and velocity of catastrophic landslides, Rock Mech. Rock Eng., 5, 231-236, doi:10.1007/BF01301796, 1973.

Srour, G.: Mine waste failure: an analysis of empirical and graphical runout prediction methods, University of British Columbia, 2011.
Take, W. A. and Beddoe, R. A.: Base liquefaction: a mechanism for shear-induced failure of loose granular slopes, Can. Geotech. J., 51, 496-507, doi:10.1139/cgj-2012-0457, 2014.

Take, W. A., Bolton, M. D., Wong, P. C. P., and Yeung, F. J.: Evaluation of landslide triggering mechanisms in model fill slopes, Landslides, 1, 173-184, doi:10.1007/s10346-004-0025-1, 2004.

Xu, Q., Peng, D., Li, W., Dong, X., Hu, W., Tang, M., and Liu, F.: Shenzhen Flowslide - GSD Rainfall Shear, available at: doi:10.13140/RG.2.2.10594.94400, 2017a.

Xu, Q., Peng, D., Li, W., Dong, X., Hu, W., Tang, M., and Liu, F.: Shenzhen flowslide - Master Cross-section Profile, available at: doi:10.13140/RG.2.2.24016.71681, 2017b.

Yin, Y., Li, B., Wang, W., Zhan, L., Xue, Q., Gao, Y., and Zhang, N.: Mechanism of the December 2015 Catastrophic Landslide at the Shenzhen Landfill and Controlling Geotechnical Risks of Urbanization, Engineering, 2, 230-249, doi:10.1016/J.ENG.2016.02.005, 2016.

Zhang, Y., Qi, M., and Ma, H.: Slope instability and its control in Shenzhen City, Chinese J. Rock Mech. Eng., 25, 3412-3421, 2006 (in Chinese).

Zou, D. H.: Exploring a Waste Dump Site Failure-Possible Causes and Prevention Measures, Int. J. Geohazards Environ., 2, 25-33, 2016. 